\title{
EARTHEN HERITAGE, CONSERVATION PRACTICES AND COMMODIFICATION IN A WORLD HERITAGE SITE (QUEBRADA DE HUMAHUACA, JUJUY, ARGENTINA)
}

\author{
J. Barada ${ }^{1, *}, \mathrm{~J}_{\text {. Tomasi }}{ }^{1}$ \\ ${ }^{1}$ CONICET - Laboratorio de Arquitectura y Construcción con Tierra, Universidad Nacional de Jujuy, Argentina - \\ ju.barada@gmail.com,jorgetomasi@hotmail.com
}

\author{
Comission II - WG II/8
}

KEY WORDS: Tourism, Commodification, Building techniques, Earthen architecture, Quebrada de Humahuaca

\begin{abstract}
:
Contemporary reflections on the conception and conservation of architectural heritage have led to new perspectives on certain categories, such as authenticity, within a more dynamic understanding of social facts. Historically, local communities have rethought and transformed their architecture within the framework of becoming reality. This change is inherent in their condition of existence, and necessary to consider the multiplicity of institutionalized actors that raise agendas and actions that intersect in a complex way with the dynamics of World Heritage sites. This paper will analyze the implications of these processes through the study of earthen architecture in Quebrada de Humahuaca (Jujuy, Argentina). The site is at risk due to the exponential growth of tourism and the process of transformation in different dimensions of local realities. Transformations in vernacular architecture will be analyze considering three dimensions and intersections. On the one hand, changes in practices of local builders within their own dynamics; on the other, the conservation actions on the architecture that have formal declarations of protection; finally, commodification of vernacular architecture due to tourist activities. The approach of this paper will focus on technical aspects, within a conceptual framework as social facts, based on the survey and fieldwork carried out in recent years. This case study could act as a precedent for similar researches and would be useful for guidelines in global earthen heritage conservation projects.
\end{abstract}

\section{INTRODUCTION}

Dynamic condition of vernacular architecture is inherent in its definition, as social itself. Conservation criteria, then, face theoretical challenges to reflect on the concept of change. These changes contribute to the preservation of values without implying an immobilization of the dynamics of society by contributing to the creation of static images anchored in past, more or less distant.

Certain places and properties, on the other hand, are subject to intense pressures related, for example, to tourism activity and to the production of imaginary within the framework of broader national and international social discussions. These processes involve concrete actions that lead to transformations in architecture, especially at local or regional level. This involves constructions with some type of declaration and the broader set of current and historical productions of many communities.

Quebrada de Humahuaca, in the north of Argentina (Figure 1), constitutes a relevant space to reflect on these processes, associated with the inclusion of certain places and properties in the World Heritage List, in relation to tensions that emerge around contrasting valorizations. In particular, Quebrada de Humahuaca was incorporated into the List in 2003 and this fact became a breaking point that intensified a set of processes that were already recognizable in the region. Because of a lack of effective management strategies, these processes could not be mitigated. With regard to the architecture of the region, the nomination had a strong emphasis on the production of colonial period (16th to 18th centuries), leaving out the immense universe of vernacular constructions, knowledge and practices.

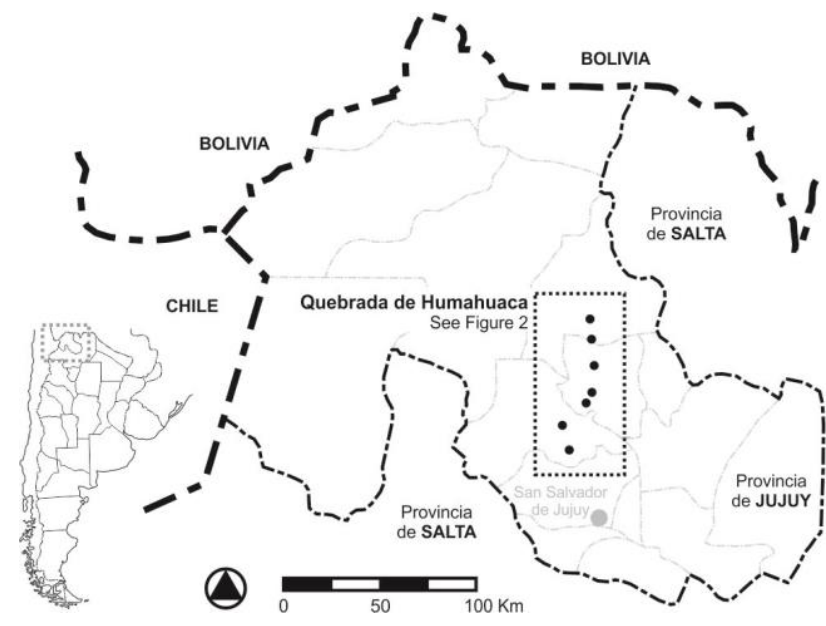

Figure 1. Location of Quebrada de Humahuaca in the province of Jujuy (C) Authors.

This vernacular architecture, fundamentally domestic, historically in the region has been based on a set of earthen building techniques both on adobe walls and mud covers ('torta de barro') roofs. In spatial terms, they have tended to be materialized in a variety of conformations around the role of the patio, with multiple variations over time in both rural and urban areas. In recent decades, it is possible to observe how some features of this architecture have been transformed within the framework of commodification processes associated with an exponential growth in tourism activity. When we speak about commodification, we refer to the process in which architectures and practices became a commodity in the framework of commercial relations.

\footnotetext{
* Corresponding author
} 
This paper proposes an approach to the Quebrada de Humahuaca case considering both the implications of its inscription on the World Heritage List and the previous processes. The analysis is based on three axes: actions and conservation policies on buildings with formal declarations, implications of the commodification associated with tourism and, finally, role that local builders have had in these dynamics. Although they can be considered independent fields of analysis, different points of linkage that exist within a complex social reality will be recognized. The reflection will focus on this case study, but observations could be relevant to consider the situation of other sites with similar problems.

This presentation is the result of various investigations carried out in the region in the last 10 years from an academic institution located in the town of Tilcara, within the Quebrada de Humahuaca. These reseaches consisted on fieldwork and archival study, particularly considering the systematic registration of different historical buildings and, more recently, in the participation in some intervention projects.

\section{QUEBRADA DE HUMAHUACA. A WORLD HERITAGE SITE IN TRANSFORMATION}

In topographic terms, Quebrada de Humahuaca is constituted as a high valley, crossed by the Rio Grande, with a development of about $120 \mathrm{~km}$ long and an altitudinal variation that goes from 1600 to 3400 meters above sea level (Reboratti, et al., 2003). Due to its location and characteristics, historically and until today, it has become an important north-south corridor, which in turn has connected high and lowlands. This particularity has been relevant in pre-hispanic and colonial times, but also in the republican period when the construction of Central Norte Railroad and later on National Route 9 that links the region with current Plurinational State of Bolivia, emphasized its condition. Within the framework of these processes, a series of villages were established, especially in the main ravine and also in subsidiaries, such as Purmamarca (Figure 2). These villages were linked to the colonization and population reduction processes in colonial times, some over pre-Hispanic occupations, and with subsequent processes such as the emergence of the railroad.

Since the end of 19th century, but particularly at the beginning of twentieth, Quebrada de Humahuaca was an object of study very relevant to the Argentine scientific field, especially because of the importance of its archaeological sites. Beyond the significance of archaeological research, registration and valorization of certain architecture in the region began to be systematic as it shows the publication of the 'Documentos de Arte Argentino' in the first half of 20th century. The emphasis on architecture corresponding to colonial period, especially ecclesiastical, as well as the studies on pre-hispanic sites, cannot be understood outside the processes and speeches associated with the consolidation of the Argentine state (Tomasi, 2012; Otero; 2013). In some way, they involved the beginning of the patrimonialization of the area.

Quebrada de Humahuaca was incorporated into the World Heritage List in 2003, after a nomination entitled 'Quebrada de Humahuaca. A 10,000-year Cultural Itinerary'. The nomination was made under criteria (ii), (iv) and (v), associated with values that focused on logic of occupation of territory and dynamics of exchange and mobility over time. The place of vernacular architecture was relegated in pursuit of a very important emphasis on production of colonial period, which ultimately recovers those researches of early 20th century. This bias would have a series of implicit problems with potentially significant impacts. First, this view implies an invisibility of later productions, including recent and contemporary ones, and practices of communities themselves, denying the meanings of vernacular architecture in its transformation dynamics. Second, and in relation to the previous, focus placed on colonial period leads to an immobilization of time, the construction of a cropped image of the complexity of historical processes.

On the other hand, interests expressed in the nomination were oriented to architecture, but not to the set of techniques associated with its production. These starting points, added to the lack of an effective Management Plan, entailed a series of significant risks due to the static conceptualization of practices and architecture intermingles without protection tools.

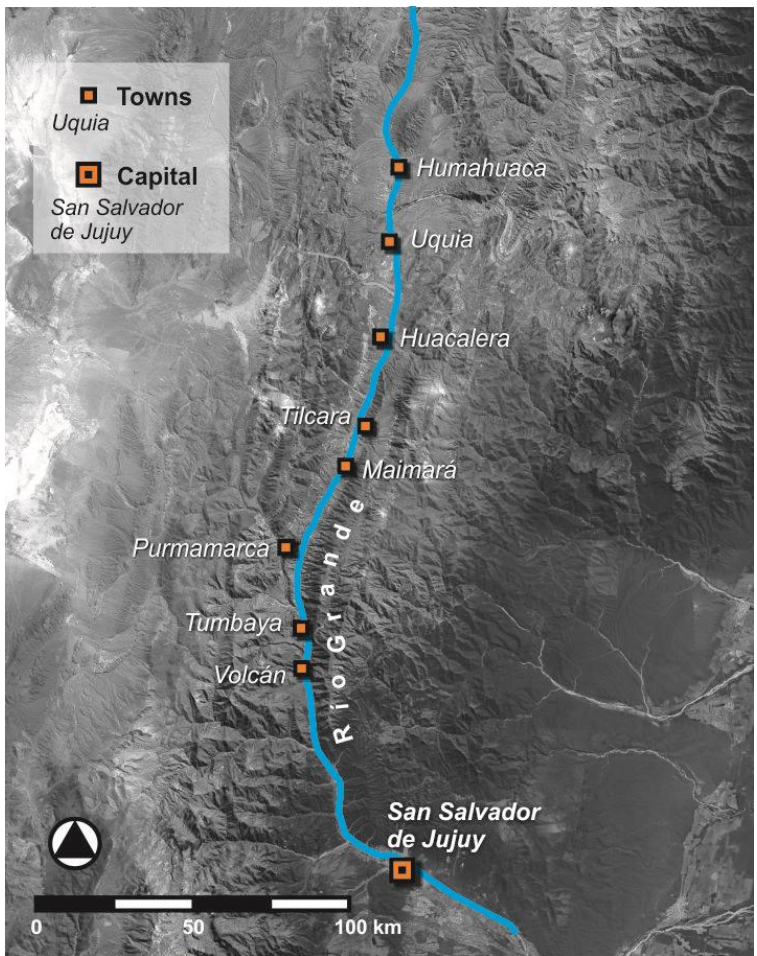

Figure 2. Quebrada de Humahuaca with some of its main towns () Authors.

This has become particularly relevant in a context where the inscription on the World Heritage List, along with other factors, implied an exponential growth in touristic activity, particularly in some locations. Although the Quebrada de Humahuaca had a certain flow of visitors since the beginning of 20th century, in the last two decades it has been multiplied with the consequent increase in the associated tourist infrastructure (Tommei, 2017), and the commodification of certain attributes of history and present of the region, including architecture (Tomasi, 2011b).

These processes present a series of issues that are a challenge for their analysis around the definition of which the recognizable risks are and how to reflect on the processes of change in the framework of practices that tend to petrify certain elements in intense transformation processes. Conservation actions on patrimonialized buildings, implications of architecture associated with tourism and practices of the builders in the region are three possible axes to analyze these processes, understanding that they are not independent spheres, but mutually constituted dynamics. 


\section{CONSERVATION PRACTICES}

The aforementioned bias in studies on architecture in northwestern Argentina was, in effect, associated with the consolidation of the state in the framework of certain nationalist discourses in which colonial past was recovered as one of the pillars for the construction of the nation (Tomasi, 2012). Associated with these investigations, first systematic policies aimed to the protection and conservation of certain historic buildings emerged, particularly, with the creation in 1938 of the current Comisión Nacional de Monumentos, de Lugares y de Bienes Históricos (CNMLyBH). Although since 1910 declarations of certain buildings as National Historic Monument (MHN) began, the creation of the CNMLyBH stablished a systematic process (Conti, 2003). By 1946, CNMLyBH declared $122 \mathrm{MHN}$, with a relevant presence of earthen buildings (Herr, Rolón, 2018). In Quebrada de Humahuaca, in 1941, an early date, six of the colonial chapels located in the towns of Tumbaya, Purmamarca, Tilcara, Huacalera, Uquía and Humahuaca were declared as MHN. All these chapels built in colonial times, as other five buildings declared in the same year in the province of Jujuy. This colonial bias expressed an emphasis on certain ecclesiastical constructions. Some features of this architecture, and not of other vernacular buildings, constituted an essentialized expression of a past that would be a source of national values. The ideas of Ricardo Rojas provided the conceptual basis for this movement (Tomasi, 2012).

During this period, systematic conservation actions began to take place. Many cases involved recovery of buildings that had been highly transformed during 19th century under the influence of European academicism. If at that time it was sought to eliminate the characteristics of colonial world, associated with the backwardness, in this new stage there was a tendency to exacerbation of the aesthetics of coloniality, now linked to its supposedly primal condition. Beyond a critical analysis of conservation practices in the first half of 20th century, it is relevant to consider how these aesthetic perspectives sustained over time, contributed to the construction of Quebrada de Humahuaca as a landscape in the strictest scenic sense.

Church of Uquía, in Quebrada de Humahuaca and located in the town of the same name, is relevant for this analysis not only for the first conservation actions in the last century, but also for recent ones. It is a chapel built in 1692, within the framework of the colonial processes of population reduction in Pueblos de Indios (Sica, 2016). It presents a single nave with an exempt tower attached to the perimeter wall that delimits the closed atrium. As already mentioned, it is a National Historic Monument in 1941, along with other chapels in the region (Figure 3). At an early stage, it had a first not documented intervention of an important scale, which can be located around the time of its declaration. Comparison between historical photographs allows to recognize how in those works the top of the tower, that was originally an adobe dome, was modified to erect a pyramid built with reinforced concrete. Beyond morphological alteration that affected the authenticity of the chapel, already a National Monument, changes in constructive system implied an alteration of senses associated with its materiality. These types of interventions multiplied in subsequent decades, with new incorporations of reinforced concrete elements.

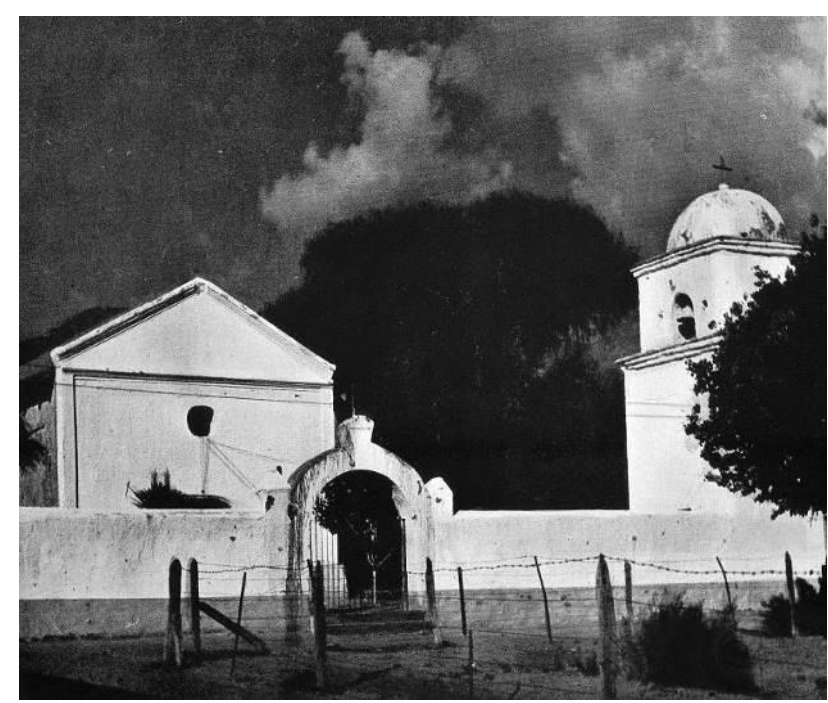

Figure 3. The Church of Uquía in a photograph from 1939 @ Academia Nacional de Bellas Artes.

Historically, the roof of the chapel was of 'torta de barro', a technique based on the execution of continuous layers of earth in a plastic state with the addition of vegetable fibers, very common in the region. Due to its characteristics, this technique provides adequate protection against rain, but requires periodic maintenance with the replacement of eroded material. Both colonial and subsequent documentation shows that lack of maintenance was the origin of recurrent pathologies in the building. Different interventions in the last decades sought to modify the characteristics of the roof in order to limit the erosion of the soil from the roof, although it implied altering the senses of the technique. In particular, in 2012, a layer of cementitious mortar of $2 \mathrm{~cm}$ was added on top of the 'torta de barro'. This shortly after favored the leaks, motivating a new modification in the cover that included the placement of a plastic mesh on the mud, painted with waterproof membrane of red color, to somehow resemble the color of soil. This solution did not prevent the emergence of new leaks, favoring the accumulation of moisture and causing serious damage to the walls.

Trajectory of interventions on the Church of Uquía allows us to recognize how conservation actions themselves can constitute an anthropic risk, not only for the authenticity and for values of the buildings, but also for their stability and preservation. This risk is a consequence of the ignorance of technologies used in the construction of buildings, and their logics and senses, but fundamentally of conceptual frameworks in the interventions. This chapel has a very important significance in devotions of local community, and at the same time, it concentrates other institutionalized assessments. The decision to use a red membrane to appeal to images of earthen construction arises from a technical mistake, but it is also associated with the production of an aesthetic within a landscape of Quebrada de Humahuaca intended for tourists (Figure 4). It implies a commodification of the historical building, detached from its local senses, destinated to the dozens of visitors who come to visit it daily during tours around the region. Like other practices and spaces of local communities, these historic buildings are a product for the consumption of a tourist market, something that also happens with vernacular architecture. 


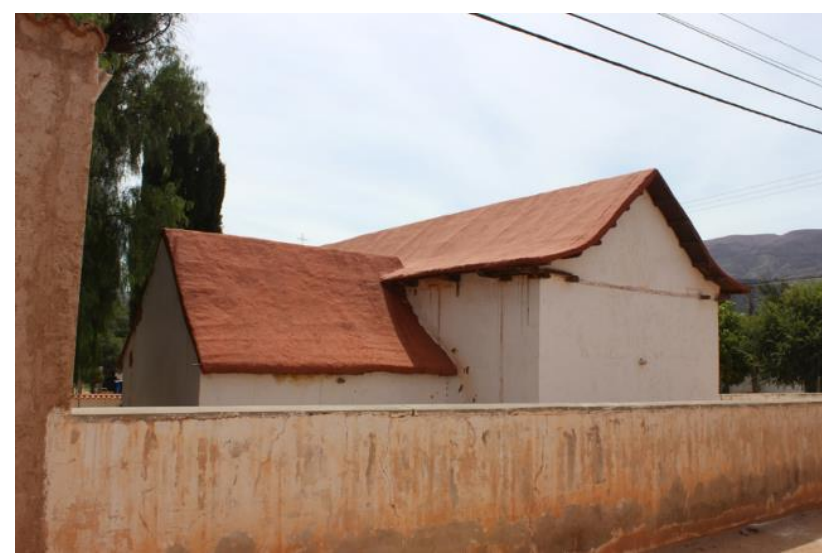

Figure 4. View of the current characteristics of the roof in the Chapel of Uquía $\odot$ Authors.

\section{TOURISM AND COMMODIFICATION}

Quebrada de Humahuaca has been a place of tourist interest since the beginning of the 20th century, specially destined for middle and upper class families from different cities of the region, who built their summer houses there. Obviously, the impact that the World Heritage declaration had in the first decades of 21 st century implied the definitive access of the area to tourist markets at national and international scale, which led to significant changes in the urban and architectural conformation of its main towns.

These changes are not limited to the aforementioned conservation strategies of monumental architecture, with heritage protection declarations, but particularly include what refers to domestic vernacular architecture, and their articulation with the development of tourist accommodation infrastructure. In the first place, there is a significant growth and densification of the towns (Vesclir et al., 2013) with an important impact on real estate valorization, associated with the growth of demand (Bratisevic, 2018). Secondly, there is a significant set of new architecture destined mainly for tourist accommodation that are both new constructions and refunctionalization of existing houses (Belli et al., 2005; Paterlini et al., 2007; Troncoso, 2009, 2013; Tomasi, $2011 \mathrm{~b}$; Tommei, 2017). The question that underlies this process is then, how did this increase occur, and, based on its interests, which is the role that vernacular architecture has in it?

Although academic and institutional views built on the architecture of the area focused mainly in the consideration of colonial productions, there has been also a sustained interest in observing the particularities of vernacular architecture. Speeches, in general, valued an apparent harmony of this architecture with their natural environments, associated with the use of raw materials from the same sites and constructive earthen techniques (Tomasi, 2012). The idea that can be extracted from these readings, such that this architecture were almost emerging from nature, operated by man only to cover his primary need for shelter, was functional to the preferential valuation of certain elements and the denial of others, enterprise that was sustained from the beginning of the 20th century until today. Thus, these discurses valued the use of certain materials and resources primarily in aesthetic terms, overlooked other aspects of architecture that have to do with its productive and social frameworks. Spatial organization of houses around a patio, dimensions of enclosures and their openings, specificity of constructive techniques and aesthetics of local senses in the domestic sphere and their practices, far from being valued, formed part of those other speeches that sought to eradicate local architecture based on a modern project (Barada, 2018).

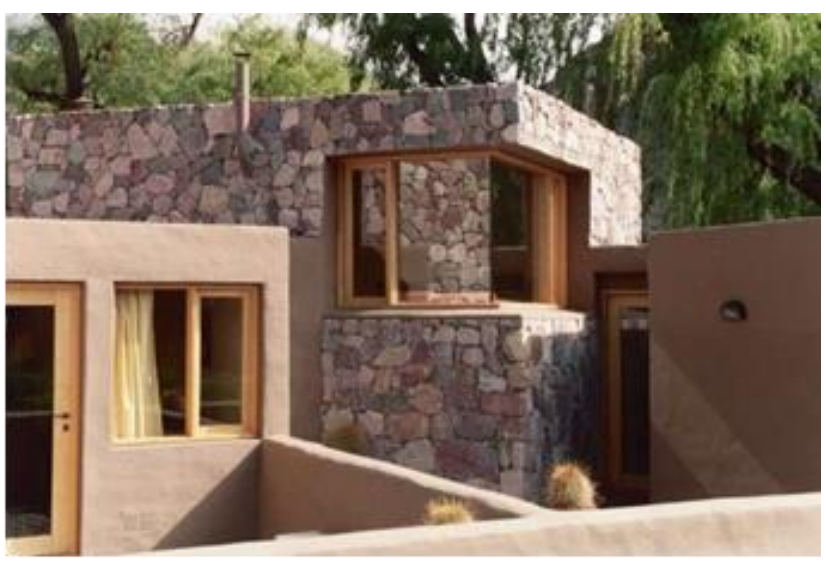

Figure 5. Details in one of the hotels of Purmamarca $(\odot$ Authors.

This tension between contrasting values has been a constant in academic and institutional discourses since the formation of the national state and its influence in the area. Heritage valuation processes and the role that vernacular architecture has had did not escaped from these tensions and 'new' architecture, produced for tourism, are one of the central objects in which since the beginning of the 21 st century, the same process materializes. On the one hand, there are certain elements considered valuable to achieve a 'vernacular image'. On the other, as it is a static image, only historical vernacular architecture, and not contemporary one, should be 'rescued'. These two ideas allow observing several conceptions about heritage that permeate these productions. They leave aside the processes of historical transformation that significantly crossed vernacular architecture and communities, many of these charged with conflict over the ownership of land, its uses, constructive materials and tourism practice (Tomasi, 2011b). Only certain elements of local architecture become esthetic objects for the production of an architecture that seeks to adapt to the environment from distinction and modernity (Figure 5).

Large hotel complexes in the towns of Purmamarca and Tilcara are good examples of this process (Figure 6). Although they attempt to maintain a similar scale of the patio houses, result in different morphological conformations. Large interior spaces are only possible by the intervention of reinforced concrete in its structure, leaving the adobe only as filling masonry (Figure 7). Same happens with openings, huge glazed windows that look for the best visuals of the landscape, far from those of small dimensions associated with the climatic condition of the area and the possibilities of adobe masonry walls in a seismic zone $^{1}$. Discourses disseminated in relation to these projects confirm these decisions: 'The original architecture is introverted because its inhabitants were in permanent contact with the immensity $(. .$.$) the case of the urban man is the opposite, he$ wants the landscape inside the house'2. This is the proposal raised in an article about the architecture of a new weekend house built in the town of Purmamarca.

Quebrada de Humahuaca is part of the Seismic Zone 2, which according to the Argentine zoning, responds to a moderate risk area. In this sense, it is important to mention that there are important studies in the Andean Area regarding adobe structures in seismic zones with even greater risk, among which those of the Pontifical Catholic University of Peru stand out.

2 Newspaper fragment, "Living” Magazine, "La Nación” Newspaper. 22 de Mayo de 2018 


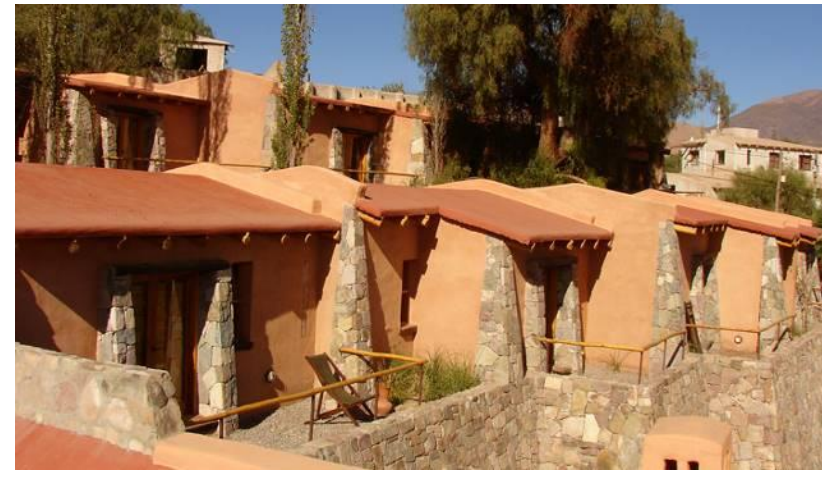

Figure 6. Residence complex in the town of Tilcara $\odot$ Authors.

In this fragment, tension referred is visible, with an architectural response that is fundamentally resolved through individual mechanisms, in a private work. Nevertheless, those mechanisms operate in the same sense on heritage than the previous discourses. In this way, this architecture produced as tourist infraestructure, beyond their variability, have 'a certain family air that allows them to be grouped together' (Tomasi, 2011b, p. 67). 'Ceilings are low because the reference measure is man and the need to give shelter (...) the outdoor environments maintain the choice of simple and practical materials that adapt to the characteristics of the place', says the same journalistic note. The 'human' scale and exterior finishes seem to be one of the main concerns of this architecture that seeks to 'revalue' local heritage. In relation to both issues, apparent harmony with the landscape attempts to be reproduced. For this, concrete plasters are painted in brown colors, pieces of wood (cactus wood) and stone coverings try to mask the reinforced concrete lintels over the openings, and clay roofs are covered in concrete and repainted with reddish membranes. As Troncoso (2013) has stated, new professional architecture receives a 'vernacular architecture bath' in its finishes (Figure 8).

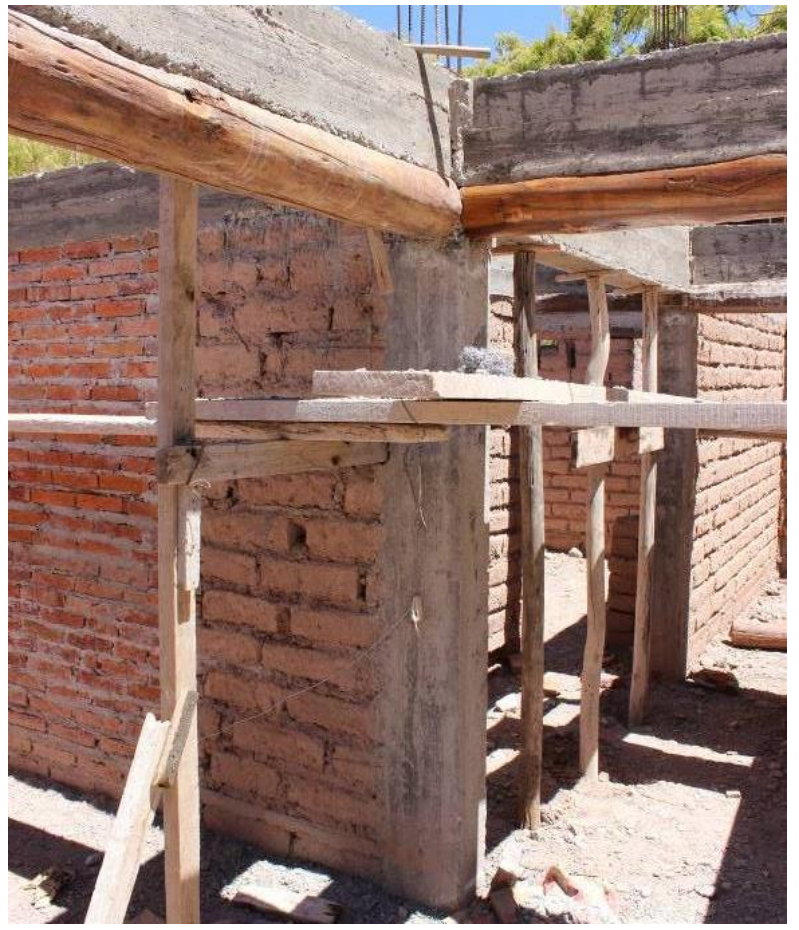

Figure 7. Wooden brace placed below a reinforced concrete beam in a new house $(\subset)$ Authors.
However, it is not only private actions that operate in this regard but also public policies, also associated with "maintaining physical characteristics that shape the historical image of the town", as is stated for the town of Tilcara. It requires constructions of a single floor and emphasizes on the characteristics of its facades. They must have a finishing plaster and its colors must be "from ranges of ocher to white, in light or very clear tones, attending to the predominant colors in each street (...) No other material seen on the facade will be allowed (no bricks, no cement blocks, or others)" ${ }^{4}$. The consequence of this type of regulations, which emphasizes the aesthetics of the materials but not their nature, leads to the use of concrete plasters, applied with a 'rustic' treatment, painted in the indicated color ranges, such as if they were mud plasters.

In this context, both private actions and regulations operate based on the preservation of a heritage whose characteristics consider the careful selection of elements, and even the simulation of some others, which supposedly belong to local tradition. Thus, discourses associated with new architecture produced in the Quebrada de Humahuaca repeats concepts that derive from those first ideas that valuated vernacular architecture of the area based on an assessment of certain elements that were functional to discourses strongly permeated by romanticism and exoticism. Expressions such as: "the rescue of the traditional", "recovering the essence of the local", "integrating with the landscape", "maintaining harmony with natural environment", are frequently used from the advertising scope, but also from media and institutions. This has been functional to the valuation of an architecture that use several aspects of vernacular one to build a tourist aesthetic focused on the sale of exoticism (Belli et al., 2005). Expressions about project decisions associated with this parcial interpretation of the vernacular are the ones that professional architecture decides to 'safeguard' from materializing in the choice of certain materials or constructive forms, stripped of their meaning.

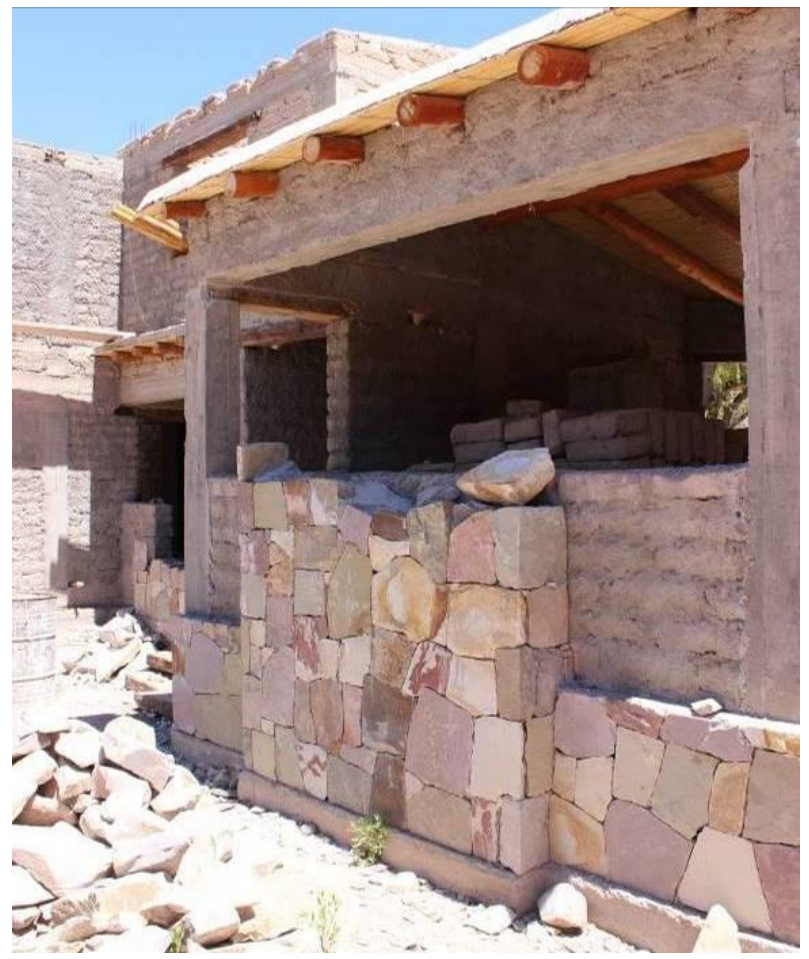

Figure 8. Stone finishing in a house in Tilcara $($ C Authors.

4 Ordinance No. 11/96, Municipality of Tilcara 


\section{BUILDERS AND TRAJECTORIES}

Architecture associated with tourism in the region is based on a conceptualization of heritage where vernacular architecture constitute as the image of a past, which ultimately does not exist as such. In this sense, it is necessary to consider the role that local populations and their architecture have had over time, from their own dynamics, considering also tourism.

At the beginning of this paper, some of the characteristics of the local architecture were pointed out. However, far from considering these characteristics as singular elements, immanent in time, for the comprehension of current vernacular production in Humahuaca it is necessary to recognize its dynamic condition, associated with both technical and social aspects. On the one hand, the specificity of earthen architecture and its techniques must be observed as processes over time that require continuous intervention on buildings (Figure 9). In line with this, analyzing production logics of domestic vernacular architecture implies observing their development, in relation to the transformation in the needs of families, their growth and their dynamics over time. Conformation of houses from successive enclosures organized around a patio is a logic sustained over time as different conformations considered at each moment have the support of certain domestic practices and senses associated with the house and the family (Tomasi, 2011a).

Historical trajectories of the communities in the area should be observed in relation to their social and productive dynamics, especially those since the beginning of the 20th century. Historically, exchange trips and caravans were part of daily dynamics of shepherds and farmers families of the Andean Area that evidently transcended current national borders. This allowed the articulation between different environments (Bugallo, 2008). Evolution of labor and commercial markets associated with the formation of national state constituted another set of mobility dynamics. This has been structural for the life of local communities, articulated with mining centers, harvest centers, tobacco companies and medium-sized cities (Parodi and Benedetti, 2016). Both dynamics have been constituents of local constructive practices, since builders were in constant exchange and observation of different architecture, techniques and materials present in the different sites. It is possible to understand the enormous variability of vernacular earthen architecture in the area, considering both its historical and spatial dispersion. Indeed, 'urban' vernacular architecture, which seek to incorporate industrialized materials, as well as morphologies from main cities, have an early presence in the area, even in small towns apparently located far from the centers of political and economic power (Barada, 2016).

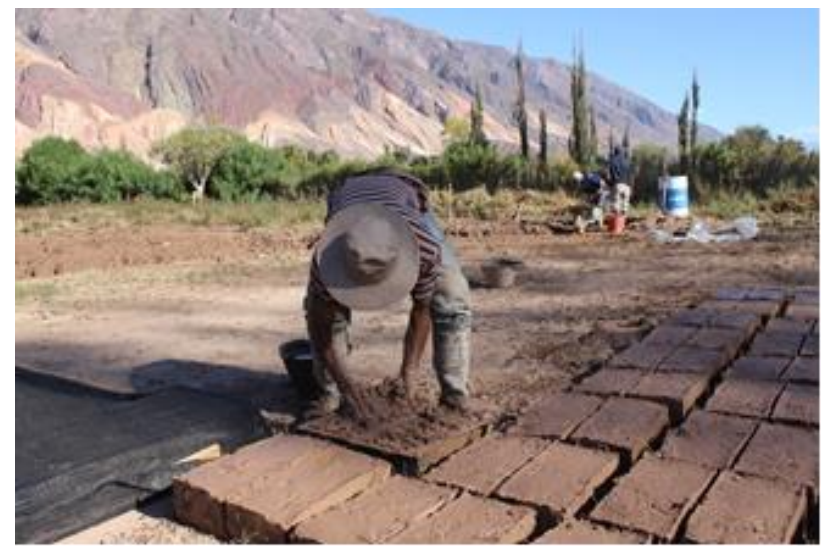

Figure 9. Adobe production in the town of Maimará () Authors.
In dialogue with a significant part of academic perspectives that sought to assess certain aesthetic aspects of the area's architecture and from different state institutions there were various speeches and actions aimed at its eradication, in pursuit of a development related to architecture which were promoted in the voice of a national modernity. Within this framework, the use of industrialized materials, particularly ceramic bricks and reinforced concrete, showed up in the Quebrada de Humahuaca through the construction of institutional buildings and in public policies. Ideas about earthen construction associated with poverty and with a short construction durability have a notable impact on the common perception of local communities.

In the interaction between social dynamics of the communities and the direct and indirect action from state institutions, it is possible to analyze the transformation that occurred throughout the 20th century in the construction systems of this architecture. Thus, reinforced concrete structures and ceramic bricks on the walls, zinc plates on the roofs and concrete plasters as finishing began to be part of the repertoire of local vernacular architecture. Those tensions can be observed also in architecture. The way in which these industrialized elements insert in local constructive logics reproduces 'ways of doing', senses and practices that are part of the vernacular universe (Barada, 2018). Changes did not happen in a homogeneous way, such that although most of new houses today are built with zinc plates as ceiling. For the walls, adobe remains the material chosen in a majority way (in fact, $80 \%$ of the houses in the area) even when it combines with reinforced concrete columns and beams (Figure 10). In turn, the way in which these materials were incorporated also strips them of their own technical universes. Thus, concrete columns and beams often do not constitute load-bearing structures, since they do not form a joint structural system. It is also frecuent to use insufficient reinforcements for the required efforts or even to place wooden structures to receive a 'torta de barro' cover although a plate finally replaces it. Likewise, concrete plaster is one of the most significant elements in the framework of these incorporations, such that it 'hides' adobe, which in the 'modern project' should be eradicated.

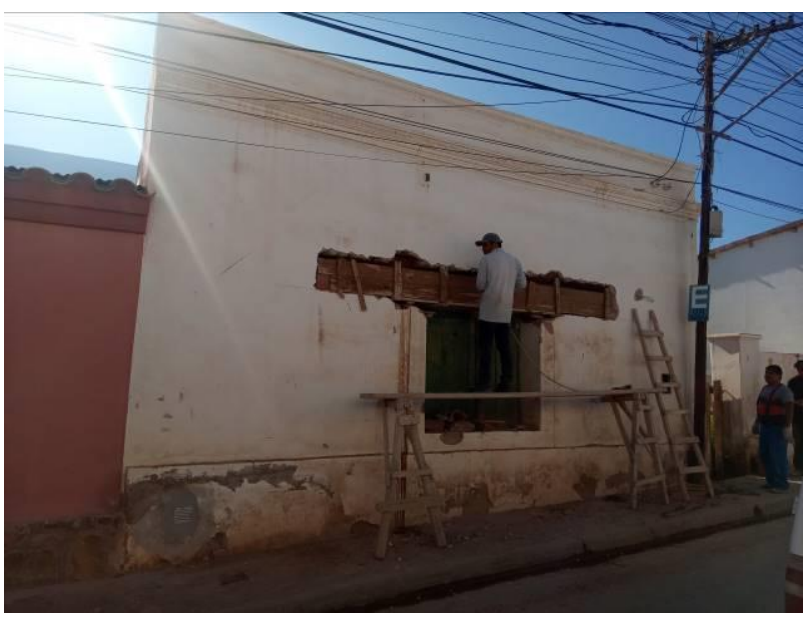

Figure 10. Adding a concrete lintel in an historic house in Tilcara (C) Authors.

This operation is exactly opposite to those promoted and carried out from professional architecture and heritage conservation projects, depending on the care of the desired heritage, masking the concrete by mud. Obviously this back and forth process constitutes a risk for the preservation of certain forms and constructive techniques historically 
developed in the area, but in the same way, and considering heritage in a dynamic way, these transformations are part, in any case, of that same heritage. A critical analysis of these processes must recognize the impact of institutional discourses on the ways of doing of communities over time, while it is necessary to consider local agencies. The latter is especially significant in terms of listening to the voices of communities and their own meanings built around their heritage, which in turn puts into crisis those productions for tourism that seek to 'revalue' an architecture that is finally not such.

\section{CONCLUSIONS}

Quebrada de Humahuaca is a region immersed in a process of intense transformations, which have occurred historically, but in recent decades presents particularities that merit an analysis. Throughout this paper, the objective was to address an analysis through three axes: conservation projects on certain constructions with formal heritage valuations, implications of tourism activity in vernacular architecture of the region, and dynamics associated with practices of local builders. Each of these axes constitutes a problem itself that enables a reflection on the risks in regional heritage. This paper was oriented to observe interactions between different dimensions of social reality and not to a deep analysis of each of these themes. It is possible to recognize several movements that have a long temporality in the dynamics of the local and the institutionalized agendas linked to the management of heritage, and between these and the processes of appropriation within the framework of tourist activity. Heritage in the region, particularly vernacular, exists as such in relations between different social actors, which may register some points of contact but have substantial differences in their conceptions and objectives. In this conflict, it is possible to find some of the most significant risk factors.

The inscription of the Quebrada de Humahuaca in World Heritage List became a factor for understanding transformations registered in vernacular architecture, uses of space and construction practices of the region. However, it is necessary to recognize that it is an intensification of long-term processes, which started, at least, at the beginning of the 20th century. Arguments presented in the nomination, where colonial architecture were emphasized to the detriment of the density of vernacular productions and their related techniques, linked to the investigations of first half of 20th century. These conceptions of heritage have modeled the criteria used in conservation projects, both historical and current. This refers to the construction of a certain aesthetic within the framework of an imagined landscape of the region, ignoring in many cases social implications of these buildings, but also the intrinsic complexity of techniques employed. At this point, there are risks to this heritage in social and material terms.

Architecture produced in the last decades destined to tourist activity are heirs of conceptions in which certain features of practices and materialities of communities are misappropriated, ignoring their production contexts and significance. In this way, there is an essencialization of certain features, which are isolated from their stories, to constitute them as consumer products within processes of commodification of heritage. In strictly architectural terms, new constructions, or old ones refunctionalized, take certain material elements to use them with new logics, avoiding social density of vernacular architecture, producing new scenarios based on artificial images constructed from the region. It is possible to observe how academic discourses and conservation actions in many buildings have tended to share these approaches to vernacular heritage.

Different valuations of heritage emerge from the conceptions of a heterogeneous set of actors that involves a diversity of local communities, state agencies linked to heritage, academic fields and different private agents oriented to the exploitation of tourism activity. These different actors do not have fixed positions, neither a static role since there have been displacements, with greater or lesser prominence of some of them over time. In any case, it is necessary to observe that, beyond these displacements, there have been asymmetric power relations sustained in relation to the construction of agendas associated with heritage conservation. In this way, place assigned to local communities in the definition of strategies and decision-making has been historically reduced, being relegated to the role of observers of these processes, while their practices and spaces have been subject to patrimonialization. This does not imply denying agency of communities, since within their own dynamics, they have been participants in these processes as observed around the practices of local builders. Although, it is necessary to recognize the general frameworks in which these relationships are established.

Problematization of anthropic risks in heritage presents important conceptual challenges to prevent its definition from being associated with the rejection of the dynamics of society over time. In this sense, more than impacts on heritage, it is necessary to observe social processes that are complex and asymmetrical, and do not partialized them. This paper has sought to propose a first approach to social complexity in the processes of patrimonialization and commodification, from the case of Quebrada de Humahuaca, understanding that there are dynamics shared with other sites in the World Heritage List.

\section{REFERENCES}

Barada, J., 2016: Algunas casas raras. Acerca de los otros patrimonios posibles en la arquitectura doméstica de la Puna argentina, Coranzulí, provincia de Jujuy. Apuntes, 29 (2), 38-55.

Barada, J., 2018: Entre casas, departamentos y viviendas. Una etnografía de las relaciones entre los pastores y el estado desde la producción de arquitectura doméstica en un pueblo puneño. Editorial Antropofagia, Buenos Aires.

Belli, E., Slavutsky, R., Argañaraz, C., 2005: Quebrada de Humahuaca: Patrimonio de la Humanidad. Capitales, Territorios y Pueblos. In: Belli, E., Slavutsky, R., Patrimonio en el Noroeste Argentino. Instituto Interdisciplinario Tilcara, Tilcara, 15-38.

Bratisevic, S., 2018: Valorización inmobiliaria reciente en la Quebrada de Humahuaca. El caso de la localidad de Tilcara. Economía, Sociedad y Territorio, XVIII (56), 291-317.

Bugallo, L., 2008: Años se manejaba el cambio y ahora el billete. Participación de poblaciones de la Puna de Jujuy en ferias e intercambios entre los siglos XIX y XX. Estudios Trasandinos, 14 (2), 5-30.

Herr, C., Rolón, G., 2018: Registro documental e intervención patrimonial en la arquitectura religiosa de la provincia de Jujuy. Criterios implementados por la Comisión Nacional de Museos, de Monumentos y Lugares Históricos (CNMMYLH) durante el período 1938-1946. Anales del IAA, 48-1, 31-45. 
Otero, C., 2013: La arqueología en el relato oficial del estado nacional. El caso del Pucará de Tilcara (Jujuy, Argentina). Arqueología Suramericana, 6 (1-2), 87-112.

Parodi, M., Benedetti, A. 2016: Minería, descampesinización y desocupación. Trayectorias de movilidad de cuatro mineros de El Aguilar (Jujuy-Argentina, década de 1940 a 2010). Estudios Atacameños, 52, 25-48.

Paterlini de Koch, O., Villavicencio, S., Rega, MA., 2007: Arquitectura popular y "modernidad apropiada" en la Quebrada de Humahuaca, Argentina: "Paisaje Cultural de la Humanidad". In: Aranda Bernal, AM. Arquitectura Vernácula en el Mundo Ibérico: Actas del Congreso Internacional sobre Arquitectura Vernácula. Universidad Pablo de Olavide, Sevilla, 366-373.

Reboratti, C., García Codrón, JC., Albeck, M., 2003: Una visión general de la quebrada. In: La Quebrada. Editorial La Colmena, Buenos Aires.

Sica, G., 2016: Procesos comunes y trayectorias diferentes en torno a las tierras de los pueblos de indios de Jujuy. Siglo XVI al XIX. Revista del Museo de Antropología, 9 (2), 171-186.

Tomasi, J., 2011a: Geografías del Pastoreo. Territorios, movilidades y espacio doméstico en Susques (provincia de Jujuy). Doctoral Thesis in Geography. Universidad de Buenos Aires, Buenos Aires.

Tomasi, J., 2011b: ¿La revalorización de lo 'tradicional' o la 'puesta en orden' de lo local? Producción arquitectónica y mercado turístico en la Quebrada de Humahuaca. In: Novick, A., Nuñez, T., Sabaté Bel, J. Miradas desde la Quebrada de Humahuaca. Territorios, proyectos y patrimonio. FADU-UPC, Buenos Aires, 63-69.

Tomasi, J., 2012: Mirando lo vernáculo. Tradiciones disciplinares en el estudio de "otras arquitecturas" en la Argentina del siglo XX. Revista Área, 17, 68-83.

Tommei, C., 2017: De ciudad huerta a pueblo boutique: territorio, patrimonio y turismo en Purmamarca, 1991-2014. Instituto de Arte Americano, Buenos Aires.

Troncoso, C. 2009: Patrimonio y Redefinición de un lugar turístico. La Quebrada de Humahuaca, Provincia de Jujuy, Argentina. Estudios y Perspectivas en Turismo, 18, 144-160.

Troncoso, C. 2013: La estetización de la Quebrada de Humahuaca (Jujuy, Argentina): turismo, patrimonio y adecuaciones de un lugar para el consumo turístico. Ería, 91, 167-181.

Vesclir, L., Tommei, C., Mancini, C. Noceti, I., 2013: Lecturas territoriales: nuevas cartografías interpretativas de la Quebrada de Humahuaca. Revista Apuntes, 26 (1), 10-31. 